\title{
Correction to: Livestock farmers' working conditions in agroecological farming systems. A review
}

\author{
Julie Duval $^{1}$ (D) Sylvie Cournut ${ }^{1} \cdot$ Nathalie Hostiou $^{1}$
}

Accepted: 14 June 2021 / Published online: 8 July 2021

(C) The Author(s) 2021

\section{Correction to: Agronomy for Sustainable Development https://doi.org/10.1007/s13593-021-00679-y}

The article "Livestock farmers' working conditions in agroecological farming systems. A review?" written by Julie Duval, Sylvie Cournut, and Nathalie Hostiou was originally published electronically on the publisher's internet portal on 17 March 2021 without Open Access. With the authors' decision to opt for Open Choice, the copyright of the article changed in June 2021 to (C) The Author(s) 2021, and the article is forthwith distributed under a Creative Commons Attribution 4.0 International License, which permits use, sharing, adaptation, distribution, and reproduction in any medium or format, as long as you give appropriate credit to the original author(s) and the source, provide a link to the
Creative Commons licence, and indicate if changes were made. The images or other third-party material in this article are included in the article's Creative Commons licence, unless indicated otherwise in a credit line to the material. If material is not included in the article's Creative Commons licence and your intended use is not permitted by statutory regulation or exceeds the permitted use, you will need to obtain permission directly from the copyright holder. To view a copy of this licence, visit http://creativecommons.org/licenses/by/4.0/.

Publisher's note Springer Nature remains neutral with regard to jurisdictional claims in published maps and institutional affiliations.
A Correction to this paper has been published: https://doi.org/10.1007/ s13593-021-00679-y

The online version of the original article can be found at https://doi.org/ 10.1007/s13593-021-00679-y

Julie Duval

julie.duval@inrae.fr

1 UMR 1273 Territoires, INRAE, VetAgro Sup, Université Clermont Auvergne AgroParisTech, F-63000 Clermont-Ferrand, France 